\title{
FLORAL SEXUAL DIFFERENTIATION IN CATASETUM FIMBRIATUM (CATASETINAE, ORCHIDACEAE) EXPOSED TO DIFFERENT LIGHT INTENSITIES
}

\author{
Cristiano Pedroso-de-Moraes ${ }^{1,5}$, Thiago de Souza-Leal ${ }^{2}$, Alinne L. Saoncella $^{3}$ \\ \& Marcílio de Almeida ${ }^{4}$
}

Biological Science Department of Centro Universitário Hermínio Ometto - UNIARARAS. Rua Maximiliano Baruto, 500, Jd. Universitário. CEP: 13.607-339. Araras/SP. Brasil

${ }^{2}$ Biological Science Department of Universidade Estadual Paulista - UNESP. P.O. Box 199, CEP 13506-900. Rio Claro/SP. Brasil.
${ }^{3}$ Biothecnology Department of Universidade Federal de São Carlos - UFSCar. P.O. Box 198, Rodovia Anhanguera, CEP: 78005-970. Araras/SP. Brasil

${ }^{4}$ Biological Science Department of Escola Superior de Agricultura Luiz de Queiróz/Universidade de São Paulo - ESALQ/USP. P.O. Box. 168. CEP: 13.915-231. Piracicaba/SP. Brasil

${ }^{5}$ Author for correspondence: cpmoraes@gmail.com

\begin{abstract}
To elucidate the factors which control the flower phenotypic plasticity of Catasetum fimbriatum, studies focusing the floral development of the species were performed. The treatments were: high light intensity $\left(1613 \mu \mathrm{mol} \cdot \mathrm{m}^{-2} \cdot \mathrm{s}^{-1}\right)$; low light intensity $\left(454 \mu \mathrm{mol} \cdot \mathrm{m}^{-2} \cdot \mathrm{s}^{-1}\right)$ and mean light intensity $\left(827 \mu \mathrm{mol} \cdot \mathrm{m}^{-2} \cdot \mathrm{s}^{-1}\right)$. The floral morphology and anatomy were analyzed to evaluate of the sequence of tissue development involved in the sexual differentiation. We found the presence of cell cluster with meristematic features in the ovaries and gynostemium of the male and female diclinous flowers. These are responsible for the definition of the sexual expression of the species, in the dependence of the environmental stimulus, related to the endogenous concentration of ethylene, allowing, consequently, the dedifferentiation and re-differentiation of those clusters in the sexual determination of the flowers. There were no anatomical differences in floral tissues in different treatments.
\end{abstract}

Key Words: Orchid, sexual expression, anatomy

Introduction. Catasetum L. C. Richard., with about 100 species (Barros et al. 2012), constitutes one of the main Brazilian orchid genera presenting high commercial value in markets due to the difficulty of sexual propagation and obtainment of hybrids (Pedroso-de-Moraes et al. 2007). Its great ornamental potential resulted in an extensive extraction in past decades, which culminated in population reduction and in the danger of extinction of countless species (Joly 1998, Moraes \& Almeida 2004).

Representatives of the genus present sophisticated specializations for the acquirement of allogamy (Zimermam 1991), which, for several decades, raised academic interest in many orchidologists and zoologists, mainly due to their adaptations to entomophily and to its flower trimorphism (Hoehne
1938, Moraes \& Almeida 2004). The difference between male and female diclinous flowers is so visual that they have already been described in distinct genera; the male ones as belonging to Myanthus, and the female ones as representatives of the Monochantus (Decker 1946).

Such phenotypical flower variations are found in the Orthocatasetum subgenus, which is characterized presenting plants in which female diclinous, male diclinous and incomplete monocline flowers take place, with such morphologic types being able to coexist in the same floral stem (Hoehne 1938, Zimermam 1991, Bicalho \& Barros 1998, Moraes \& Almeida 2004). This floral form began several controversies concerning its derivational state and ecophysiological aspects due to the diverse range of results related to 
its sexual expression found by researchers (Zimermam 1991, Moraes \& Almeida 2004).

Information about the anatomy of gynostemium is scarce in the literature, mainly due to the difficulty in preparing them for microscopy (Arditti 1992), which strongly limits the study of this extremely important structure in orchids. However, the current state of knowledge is that the gynostemium, comprising stamen filaments adnate to a syncarpous style, occurs in only three groups of monocots, all of them epigynous lilioids: Orchidaceae (Asparagales), Pauridia (Hypoxidaceae: Asparagales) and Corsia (Corsiaceae: Liliales). A new term, hyper-epigyny, was proposed to describe stamen adnation to the style, which may be a product of over-expression of genes controlling epigyny (Rudall \& Bateman 2002). The studies on such organs were performed with orchids of Bulbophyllum (Rasmussen 1985) and Phalaenopsis (Arditti 1992) and with representatives of the Diurideae and Cranichideae tribes (Kurzweil et al. 2005).

The continuous destruction of the natural habitat of the genus sets its existence at risk justifying, therefore, more detailed studies on Catasetum fimbriatum (C. Morren) Lindl. Such endangered species is one of the most commercialized of the genera (Pedrosode-Moraes et al. 2007, Brescasin et al. 2013), which implies in the need for elucidation of the questions related to their sexual expression. Such knowledge would enable the development of handling techniques which guarantee greater reproductive success in restoration and conservation projects and to obtain hybrids for commercial genetic improvement.

The objectives of the work are to perform the anatomical study of gynostemia and ovaries in different phases of development and to clarify the morphological mechanisms involved in flower development of this species, under the influence of different light intensities, which can act in the sexual determination of its flowers.

Material and methods. Forty-five plants of Catasetum fimbriatum from Nursery of the Escola Superior de Agricultura Luiz de Queiróz - ESALQ/ USP, Piracicaba, SP, were used. A voucher specimen was prepared according to the usual herbarium techniques (Mori et al., 1989) and stored at the Herbário Rio Clarense (HRCB), of the Instituto de
Biociências de Rio Claro, Universidade Estadual Paulista - UNESP, under the number: 45344.

For the experiments, plants were analyzed at physiological maturity (with four pseudobulbs owning scars indicating the emission of inflorescences) and in dormancy period (without new pseudobulb development or any sign of new rooting) (Pedrosode-Moraes 2000). The specimens were divided in three treatments containing 15 plants each. Treatment 1 (T1) was characterized by the exposure of the plants to monthly average intense light, $1613 \mu \mathrm{mol} . \mathrm{m}^{-2} \cdot \mathrm{s}^{-1}$, obtained by the use of $20 \%$ shade cloth as the nursery covering. Treatment 2 (T2) was characterized by the exposure of the plants to monthly average low light intensity, $454 \mu \mathrm{mol} . \mathrm{m}^{-2} . \mathrm{s}^{-1}$, by the use of $80 \%$ shade cloth. And the third one, considered control, Treatment 3 (T3) was characterized by the study of the plants under natural phorophytes, Acrocomia aculeata (Jacq.) Lood. ex Mart. (Arecaceae), with mean height of $8 \mathrm{~m}$, under mean natural light intensity of $827 \mu \mathrm{mol} . \mathrm{m}^{-2} \cdot \mathrm{s}^{-1}$. The light intensities were measured once a week using a quantum sensor associated to a data-log ( $\mathrm{Li}$ - 1400, LI-COR, Lincoln, NE, USA).

The gynostemia and the ovaries of male and female flowers were fixed in Karnovsky's solution (Karnovsky 1965 ) and subjected to a vacuum pump for the removal of the air contained in the intercellular spaces for 2 hours. After the fixation, the samples were dehydrated in ethyl alcohol series and infiltrated with ReichertJung's glycol-methacrylate resin. The sections were cut in hand rotary microtome (Leica, Solms, Germany) with type $\mathrm{C}$ knife at 5 micrometers of thickness, stained with $0.05 \%$ toluidine blue in citric acid phosphate buffer (O'Brien et al. 1964) and mounted on "Entellan" synthetic resin (Merck, Whitehouse Station, NJ, USA). The slides were photomicrographed, and the scales were obtained in the same optical conditions used for the slides. The epidermal analysis and the Protoplasm Nucleus Relation (PNR), occurred by use of AnatiQuanti software.

For each treatment, three samples were made in different stages: emergence of the floral bud (first week), intermediate stage (third week) and finally, the anthesis stage (five week). From bud differentiation to opening of the flower takes approximately five weeks (Joly 1998). 
TABLE 1. Total number of female and male diclinous flowers occurring in Catasetum fimbriatum.

\begin{tabular}{c|c|c}
\hline Treatment / Light Intensity $\left(\mathrm{mmol} \cdot \mathrm{m}^{-2} \cdot \mathbf{s}^{-1}\right)$ & $\begin{array}{c}\text { Total number of female diclinous } \\
\text { flowers }\end{array}$ & $\begin{array}{c}\text { Total number of male diclinous } \\
\text { flowers }\end{array}$ \\
\hline $1 / 1613$ & 33 & 72 \\
$2 / 454$ & 5 & 270 \\
$3 / 827$ & 16 & 183 \\
\hline
\end{tabular}

By obtaining 15 flowers of both sexes on the installed treatments, subdivided into three lots, each containing five flowers, the morphometric analyses of the ovary and gynostemium were performed, in which the following flower characteristics were analyzed: mean length and diameter of the ovary; and mean length, width and thickness of the gynostemium. Means concerning the length and diameter of the fruit originated during the experiment were also obtained. The results acquired were subjected to ANOVA and compared through the Tukey test at 5\% (Zar 1999). The total number of flowers of both sexes occurring in the treatment was also measured. As the chosen plants presents four pseudobulbs of similar size, was not included in the ANOVA covariates related to the size of the plants.

\section{Results}

Flower sexual differentiation influenced by light. Treatments with higher light intensities (T1 and T3), promoted higher number of female diclinous flowers, 33 and 16, respectively, while the T2, with lower light intensity (T2), presented only 5 diclinous flowers. The total number of male diclinous flowers showed an opposite relationship with light intensities, with 270 male diclinous flowers obtained in T2, 183 in T3 and 72 in $\mathrm{T} 1$ (Tab. 1). In five plants of T3, the formation of female and male diclinous flowers took place in the same flower stem. The emergence of monoclinous flowers was not observed during the monitoring period.

Reproductive morphology and anatomy. - The ovaries of all flowers analyzed were cylindrical. However, in the female flowers were widely curved and had superficial indicative depressions in the place of carpel fusion, while the ovaries of the male diclinous flowers were completely smooth and straight (Figs 1-3).

The statistical analysis performed for the flowers of all treatments indicated significant differences concerning the morphometric traits under the light settings evaluated. The plants treated with lower mean light intensity (T2) produced flowers with higher mean length of the ovaries and gynostemium of both sexes. Nevertheless, the plants treated with higher mean light intensity (T1), presented the greatest mean ovary diameter, thickness and width of the gynostemium of the female flowers. However, no statistically significant differences were found on the ovary diameter gynostemium and thickness and width, between the three light settings in the male flowers (Tab. 2).

The epidermis in all ovaries analyzed, independently of both the flower sexual expression and light intensity to which the flowers were exposed to, were one-layered and covered by thin cuticle (Figs. 4-5).

The loculi were totally filled with parenchyma tissue, in which, it observed collateral closed vascular bundles and aggregated to meristematic cells (Figs. 5-7arrows). Can be observed in the cross and longitudinal sections, for all light intensities, in the mesophyll of the ovaries of female (Figs. 4-6) and male (Fig. 7) flowers there are areas where cell clusters are different from the rest of the tissue in the anthesis phase. In these areas, the cells divide themselves in a periclinal way and are isodiametric and with high Protoplasm Nucleus Relation (PNR). These are different from the rest of the parenchyma cells, in which anticlinal divisions predominate (Figs. 6a, 7a).

The fruits, characterized as capsules, with parietal placentation (Fig. 3), present inside an abundance of trichomes formed by $4-5$ cells with mean length and diameter of 8.75 and $5.92 \mathrm{~cm}$.

The gynostemia analyzed are formed by the pistil adnation in female diclinous flowers and by stamens in male diclinous flowers. Therefore, the gynostemia of female flowers are characterized by presenting body, rostellum and stigma (Figs. 8-10), while the ones of the male flowers present body, non-functional stigma, rostellum, stipe, caudicle and pollinaria (Figs. 11, 12). 

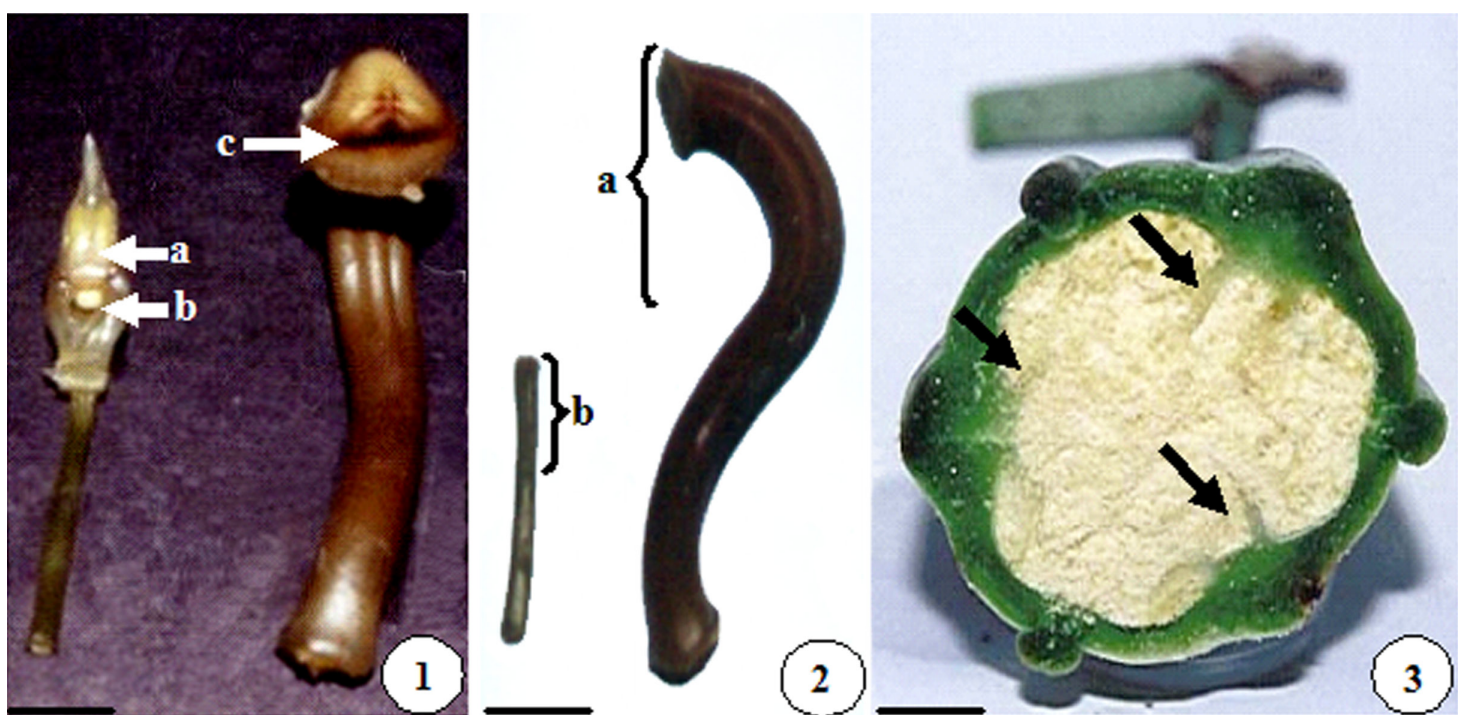

FIGURES 1-3. Gynostemia and ovaries of male and female diclinous flowers in anthesis of Catasetum fimbriatum (C. Morren)

Lindl. 1, Male flower (left); (a), pollinea; (b) non-functional stigma; (c) female flower stigma (right). 2, Ovary of male (smooth and straight) and female flowers; (a) ovary of the female diclinous flower; (b) non-functional ovary of the male flower (smooth and straight). 3, Cross section of the fruit capsule. Arrows = fusion of the carpel edges. The internal portion of the fruit is filled by seeds. Scales: $1 \mathrm{~cm}$.

In the gynostemium of the female flowers there is a vascular bundle in the ventral portion of the structure (Fig. 8, arrow), while in the male one, a bundle is located in the dorsal portion.

For all light intensities, the body of the gynostemia of flowers of both sexes consists of small isiodiametric cells (Figs. 8, 11, 13-15) which present dominance of anticlinal cell divisions. However, in the upper part of the gynostemium of female diclinous flowers, in the exact site where in the male flowers the pollinaria is originated, the presence of a cell cluster whose cells are isodiametric can be observed, which are divided in a periclinal way and present high PNR (Figs. 10, 10a). Concerning the stigmas, it can be seen that, in all the development phases, they presented the same shape and that between the mean development period and the

TABLE 2. Means of the reproductive morphometric traits of male and female diclinous flowers of Catasetum fimbriatum submitted to different light intensities. $\mathrm{VC}=$ Variation Coefficient.

\begin{tabular}{|c|c|c|c|c|c|}
\hline \multirow{3}{*}{$\begin{array}{l}\text { Light intensity } \\
\left(\mu \mathrm{mol} \cdot \mathrm{m}^{-2} \cdot \mathrm{s}^{-1}\right)\end{array}$} & \multicolumn{5}{|c|}{ Female flowers } \\
\hline & \multicolumn{2}{|c|}{ Ovary } & \multicolumn{3}{|c|}{ Gynostemium } \\
\hline & Length (cm) & Diameter (cm) & Length (cm) & Thickness (cm) & Width (cm) \\
\hline $1613(\mathrm{~T} 1)$ & $3.73 c$ & $1.96 \mathrm{a}$ & $1.88 \mathrm{c}$ & $1.32 \mathrm{a}$ & $1.46 \mathrm{a}$ \\
\hline 454(T2) & $4.85 \mathrm{a}$ & $1.21 \mathrm{~b}$ & $2.34 \mathrm{a}$ & $1.14 \mathrm{~b}$ & $1.21 \mathrm{~b}$ \\
\hline 827(T3) & $4.25 \mathrm{~b}$ & $1.23 \mathrm{~b}$ & $2.01 \mathrm{~b}$ & $1.19 \mathrm{~b}$ & $1.27 \mathrm{~b}$ \\
\hline \multirow[t]{2}{*}{ VC (\%) } & 6.38 & 4.87 & 6.21 & 7.08 & 8.14 \\
\hline & \multicolumn{5}{|c|}{ Male flowers } \\
\hline \multirow{2}{*}{$\begin{array}{l}\text { Light intensity } \\
\left(\mu \mathrm{mol} \cdot \mathrm{m}^{-2} \cdot \mathrm{s}^{-1}\right)\end{array}$} & \multicolumn{2}{|c|}{ Ovary } & \multicolumn{3}{|c|}{ Gynostemium } \\
\hline & Length (cm) & Diameter (cm) & Length (cm) & Thickness (cm) & Width (cm) \\
\hline 1613(T1) & $1.02 b$ & $0.47 \mathrm{a}$ & $2.62 \mathrm{c}$ & $0.78 \mathrm{~b}$ & $0.81 \mathrm{a}$ \\
\hline 454(T2) & $1.54 \mathrm{a}$ & $0.52 \mathrm{a}$ & $3.78 \mathrm{a}$ & $0.73 b$ & $0.82 \mathrm{a}$ \\
\hline 827(Т3) & $1.21 \mathrm{~b}$ & $0.48 a$ & $3.11 \mathrm{~b}$ & $0.75 b$ & $0.82 \mathrm{a}$ \\
\hline VC (\%) & 3.25 & 2.42 & 9.92 & 1.12 & 1.12 \\
\hline
\end{tabular}

Numbers followed by same letters in the same column do not differ between themselves by the Tukey test at $5 \%$. 

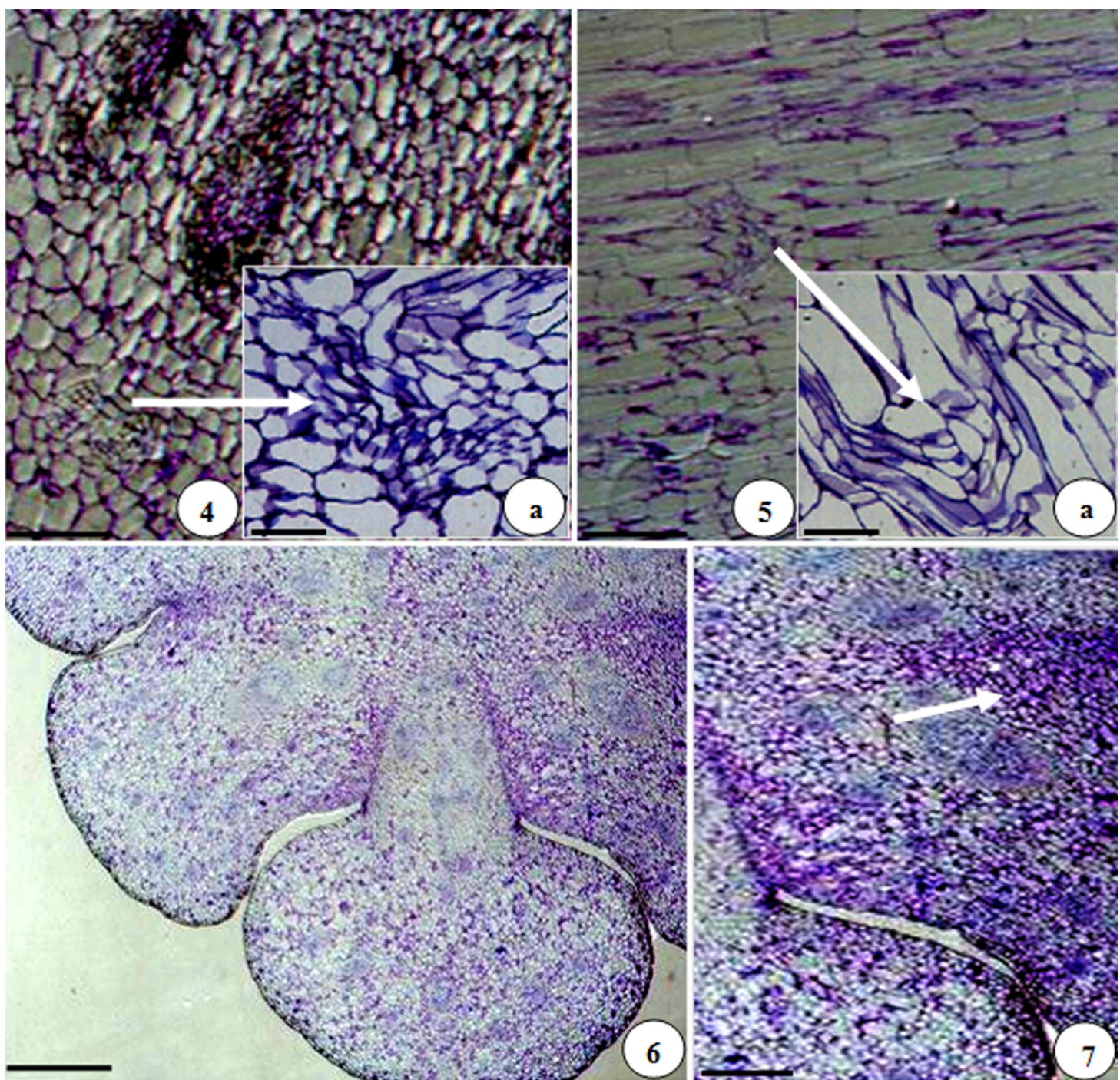

FIgURES 4-7. Cross and longitudinal sections of ovaries of mature flowers of Catasetum fimbriatum (C. Morren) Lindl. in the anthesis phase. 4 , cross section in ovary of female diclinous flower. 5 , detail of the cross section in ovary of a female diclinous flower, the arrow indicates the place of the ovule formation. 6 , transversal section of the ovary of a female diclinous flower; (a) detail of evidencing meristematic cell cluster (arrow region). 7. longitudinal section of the ovary of a male diclinous flower. Detail evidencing meristematic cell cluster (arrow). Scales: 4,6,7 = 100 $\mu$ m; $5=50 \mu \mathrm{m} ; \mathrm{a}=7 \mu \mathrm{m}$.

anthesis, the genesis and subsequent maturation of the secreting cells of viscine took place (Fig. 9, arrow).

The gynostemium of male diclinous flowers present body, rostellum, stipe and caudicle formed by small parenchymatic isodiametric cells with small cell spaces, without any other cell detail (Figs. 11, 12). The pollinaria, inserted in upper projection of the caudicle, is formed by two groups of pollinia which appear in upper ventral position, and which presents small cells of dense intracellular content (Figs. 12).

Unlikely the female diclinous flowers, during the development of the gynostemium, stigmatic morphologic changes can be observed in the male flowers. In them, such structure, in the initial development period, presents infolds in the basal and medial portions and trident-like shape in the upper 

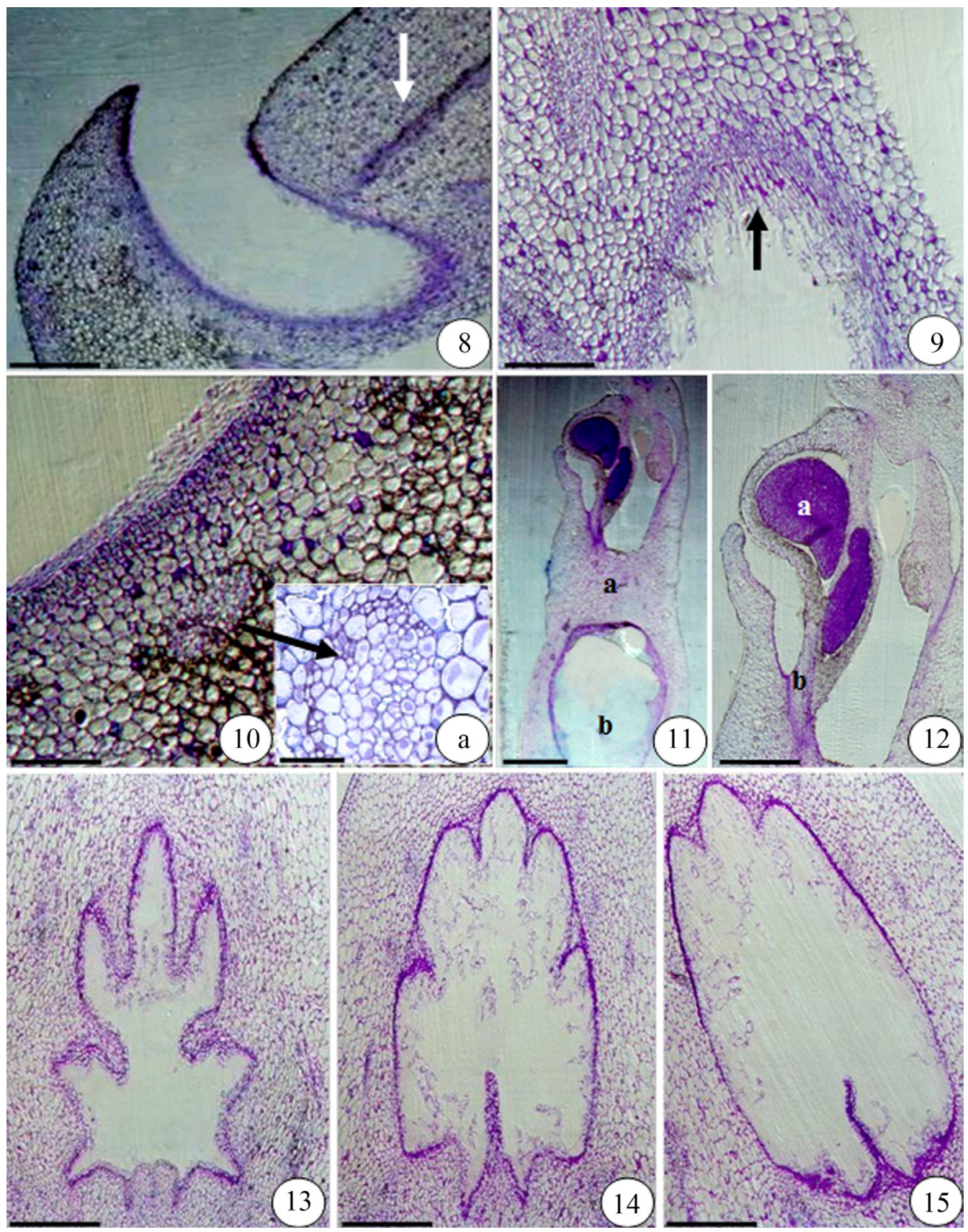

FIGURES 8-15. Longitudinal sections in gynostemia of flowers of Catasetum fimbriatum (C. Morren) Lindl. 8-9, longitudinal section in distal portion of the gynostemium of a female diclinous flower; arrows evidence the vascular bundle from the rostellum (white) and secreting cells of viscine adhered to the stigma (black). 10, longitudinal section in the stigmatic portion of the female diclinous flower; (a) cell cluster. 11, longitudinal section of the gynostemium of a male diclinous flower in the anthesis phase; (a) rostellum; (b) non-functional stigma. 12, longitudinal section in gynostemium of a male diclinous flower in anthesis phase; (a) pollinaria; (b) stipe. 13-15, longitudinal section in stigmas of male diclinous flowers in different phases of development (openings in the center of the image). 13, primordium of the flower bud formation. 14, intermediate development phase. 15 , anthesis. Scales: $8-15=120 \mu \mathrm{m}$; $\mathrm{a}=15 \mu \mathrm{m}$. 
part (Fig. 13). It can be seen that such morphologies change gradually in the initial period, going through an intermediate development phase until they take the final shape in the anthesis, in which occurs the disappearance of the infolds in the medial and basal region and attenuation of the trident-like aspect of the stigma in the upper part (Figs. 14-15).

\section{Discussion}

Sexual floral differentiation influenced by light. - The ovarian depressions occurring in the female flowers, resulting in morphology similar to the flower display usually found in flowers of Orchidaceae. The results of the anatomical ovarian assessment of flowers of both sexes in different phases of development and light intensities allowed the classification of the ovaries as three-carpelated and unilocular, with the fruit formation taking place only after the pollination.

The results obtained suggest that the occurrence of sexual differentiation in Catasetum fimbriatum is directly influenced by the exposure to different light intensities. Such observation is corroborated by similar data found for some species of Catasetum and Cycnoches (Gregg 1975, Aronovitz \& Aronovitz 1976, Batchelor 2001) and for: Catasetum barbatum, under cultivation (Soukup 1976) and Catasetum viridiflavum, in natural conditions (Zimmermam 1991). Thus, the exposure of $C$. fimbriatum to high light intensities induces, predominantly the differentiation of female diclinous flowers and the exposure to more shading settings, male diclinous ones. The monoclinic flowers, therefore, only appear when there is great variation in the light intensity of the environment (Moraes \& Almeida 2004, Pedroso-de-Moraes 2004, Pedrosode-Moraes \& Almeida 2005, Brescansin et al. 2013). However, evidence shows that certain representatives of the Catasetinae subtribe generate female diclinous flowers not only when exposed to intense luminosity, but also, due to nutritional lack (Zimmerman 1990, Arditti 1992) and aging (Freeman et al. 1980), factors which may act synergistically with light.

Such statements are corroborated by the fact that plants with sexual dimorphism have their sexual expression influenced by their nutritional status, age states and by variations in the rates of exposure to solar radiation, independently of the genetic traits they present (Taiz \& Zeiger 2006, Kerbauy 2009).
The sexual reversion by hormonal action indicated in some plants, the genes required for the development of the androecium and gynoecium are functional, but silenced. Thus, the action of a hormone to feminize and masculinize flowers can have effects totally different in many plants, since this variation reflects the different mechanisms studied concerning the sexual determination (Dellaporta \& Calderon-Urrea 1993).

From the observation that the $C$. fimbriatum is a monoecous species, with genetic-hormonal flower sexual determination system and, also, according to the results obtained in the treatments performed, it becomes possible to hypothesize that auxin and ethylene can be a component of the environment sensory mechanism associated with flower phenotypic plasticity of the species. Hence, the balance between the endogenous levels of these phytohormones triggers the floral sexual differentiation. In this species, it is worth investigating the mechanism in which the increase of the synthesis of auxins and the decrease of the ethylene levels determine the occurrence of male diclinous flowers, and the opposite situation, in relation to the phytohormones (Brescansin et al .2013), the occurrence of female diclinous flowers, as has been described for several species of monocotyledons (Taiz \& Zeiger 2006, Kerbauy 2009). The monoclinic flowers, therefore, likely would only appear when the endogenous levels of auxins and ethylene occurred in extremes which are consistent with their appearance following by female, male or both diclinous flowers.

Reproductive morphology and anatomy. - The existence of one-layered epidermis and the presence of mesophyll before pollination, observed for all the ovaries of flowers of both sexes in different light levels, it's in accordance with the descriptions made to orchids of different habitats in Orchidoideae and Epidendroideae subfamilies (Arditti 1992). Such features only differ in some representatives of the Apostasidoideae, where a collenchymatose hypodermis are found under the epidermal cells, related to the mechanical protection of ovaries under development (Solereder \& Meyer 1930). Moreover, the parietal placentation is described according with the observed for innumerous species belonging to the phylogenetically more derived subfamilies, 
Cypripedioideae, Vanilloideae, Orchidoideae and Epidendroideae (Arditti 1992, Pridgeon et al. 2001, 2003, 2006, 2009) in relation to Apostasidoideae, in which the species present free central placentation (Solereder \& Meyer 1930, Pridgeon et al. 1999).

Ovaries of many orchids of different subfamilies can present trichomes internally, which can vary widely in size and shape, and may or may not contain anthocyanin pigment (Arditti 1992). The function of the trichomes is not completely clear, but it is described as related, mainly, to the mechanical protection of the ovary and fruit (e.g., Arditti 1992). The presence of anthocyanin in these structures can be interpreted as protection against light occurs in fruits (Taiz \& Zeiger 2006), since epiphyte species can be subjected to high light intensity (Perleberg et al. 2008).

The cell clusters found in the ovaries analyzed in the anthesis of female and male diclinous flowers, due to their features, can be classified as meristematic clusters (Esau 1980, Cutter 1992), capable of originating ovules under the appropriate hormonal stimulus. Such suggestion is corroborated by the fact that the orchids produce ovules through differentiation of the parenchymatic/meristematic tissue, only after pollination, and such differentiation is stimulated by chemical substances produced by the deposit of pollinia mass in the stigmatic cavities (Arditti 1992).

The vascular anatomy of the ovaries of the flowers of both sexes is in accordance with the one described for the Orchidaceae. Vascular bundles originated from the flower rachis develop through the whole extension of the pedicles and originate many vases which irrigate each one of the carpels (Swamy 1948).

The gynostemium feature is an extremely specialized structure which, consequently, defines the Orchidaceae. In this species, the gynostemium is formed by the partial fusion of the androecium and gynoecium in Apostasidoideae (Pridgeon et al. 1999) and total fusion in Vanilloideae, Cypripedioideae, Orchidoideae and Epidendroideae (Pridgeon et al. 2001, 2003, 2006, 2009). However, in Catasetinae (Epidendroideae) the exception is in diclinous flowers, found in plants such as Catasetum fimbriatum.

How described for the flowers analyzed in this work, anatomical studies in gynostemia of Bulbophyllum, Cranichis, Diuris and Phalaenopsis (Rasmussen 1985, Arditti 1992, Pridgeon et al. 2001, 2003) showed that in these taxa, this organ presents body, rostellum, stipe and caudicle without any clear anatomical detail and formed by small isodiametric parenchymatic cells which form the tissue which predominates anticlinal cell divisions and small intercellular spaces.

There are three basic patterns described concerning the origin and nature of the stamen and stigma vascularization for gynostemium in Orchidaceae. The most important vascular bundles described for the monoclinous gynostemium appear in the following way: - A1, bundle which ramifies from the main dorsal and which supplies the functional stamen; G1, G2 and G3, bundles which ramify from the main ventral and which extends to the inside of the rostellum and stigmas and, A2 and A3, which ramifies from the main dorsal and goes to the side stamens of the beginning of the verticil (Swamy 1948). Thus, in monoclinous flowers of the family, generally, two vascular bundles, a ventral one and a dorsal one, originate the secondary ramifications. With the first vascular bundle ramifying itself near the rostellum and stigma and the other one in the pollinia region (Arditti 1992, Romero 1992). Once more, the existing difference between the monoclinous and diclinous gynostemium is evidenced (Romero 1992). In the female diclinous gynostemium, unlikely the monoclinous, the only vascular bundle is near the stigma region. However, in the male diclinous gynostemium, the bundle gets closer to the pollinia, as in monoclinous gynostemium.

As described before, unlike the male diclinous flowers, secreting cells can be found in the stigma of the female flowers. This corroborates with the statement that the stigmas of several species of Orchidaceae are covered by pappilary secreting cells, which in general are enlarged, vacuolated, of prominent nucleus and which produce secretions of mucopolysaccharid acids (Arditti 1992, Kurzweil et al. 2005).

The stipe is an attachment of the pollinaria derived from the rostellum. The caudicles are found adhered to it, while it is joined in the final portion of the viscidium. In some orchids, the joint is easily seen, as in the studied species, but in others its distinction becomes extremely difficult (Arditti 1992).

As evidenced in this study, the caudicles, in general, do not have any cell detail and are very elastic. Their cells are viewed as a meristematic mass adjacent to the pollinia (Kurzweil et al. 2005). They are small, 
dense and of two kinds: cells of thick walls and cells of thin walls. In the center of the mass, the thick-wall cells are similar to the ones which develop the pollen. The cytoplasm of vegetative cells in the maturity is dense and contains a prominent nucleus, numerous mitochondria and plastids. The generative cells are small, have a prominent vacuole and dense nucleus, but a limited number of organelles. The exine of the caudicle, as the one of the pollinia, is composed at first of sporopollenin, as evidenced by its resistance to the acelolyses (Arditti 1992, Kurzweil et al. 2005).

The cell clusters formed by typically meristematic cells, found in the ovaries and located right above the female diclinous flower stigma, are evidence, once more, that the differentiation of flowers of both sexes is triggered by environmental stimulus, detected commonly in plants by phytochromes (Gates 1981, Nobel 1991), which determine the synthesis of phytohormones. Thus, in this area, when there is the appropriate phytohormonal stimulus, such cells differentiate to form the pollinia. This finding is supported by the detailed studies on morphogenetic sexual organs of many species, which evidences that either male or female diclinous flowers often go through a monoclinous stage, in which all the organs are initiated (Dellaporta \& Calderon-Urrea 1993).

Therefore, the formation of diclinous flowers originated from monoclinous meristems requires the action of sex-determining genes (Dellaporta \& Calderon-Urrea 1993), since the ability to reverse the mechanism of sexual determination through treatment with vegetal regulators (Taiz \& Zeiger 2006), suggests that the flower prime has evidences of inappropriate sexes, being bipotent, and that the sex-determining genes regulate alternative programs of sexuality, possibility through signaling from translation mechanisms which modify the endogenous concentrations of phytohormones (Dellaporta \& Calderon-Urrea 1993).

Conclusions. In face of the results obtained in the morphogical and anatomical flower analysis for the definition of the sequence of tissue development involved in sexual differentiation, it can be seen the presence of cell clusters with meristematic features in the ovaries and gynostemia of the female and male diclinous flowers, which are possibly responsible for the definition of sexual expression of the species, in the dependence of the environmental stimulus, related to the endogenous concentration of ethylene, allowing, therefore, the dedifferentiation and re-differentiation of those clusters in determining the flower sexes.

\section{LiTERATURE CITED}

Arditti, J. (1992). Fundamentals of orchid biology, New York: John Wiley.

Aronovitz, G. H. \& Aronovitz, A. V. (1976). Some light on Catasetum Francis Nelson 'Avis', AM/AOS. American Orchid Society Bulletim, 45(7), 614-619.

Barros, F., Vinhos, F., Rodrigues, V. T., Barberena, F. F. V. A., Fraga, C. N. \& Pessoa, E. M. (2012.). Orchidaceae. In: Lista de Espécies da Flora do Brasil. Jardim Botânico do Rio de Janeiro. Available in: <http://floradobrasil. jbrj.gov.br/2012/ FB011312> Access: 03 mar. 2013.

Batchelor, S. R. (2001). Your First Orchid: A Guide for Beginners. Coral Gables: American Orchid Society.

Bicalho, H. D. \& Barros, F. (1988). On taxonomy of Catasetum subsection Isoceras. Lindleyana, 3(2), 87-92.

Brescansin, R. L., Souza-Leal, T., Pedroso-de-Moraes, C. (2013). Influência de diferentes substratos e concentrações de acetileno na floração de Catasetum fimbriatum (C. Morren) Lindl. \& Paxton (Catasetinae, Orchidaceae). Revista Brasileira de Biociências (Online), 11(4), 191-196.

Cutter, E. G. (1992). Plant Anatomy. London: E. Arnold.

Decker, J. S. (1946).Cultura das orquídeas no Brasil, São Paulo: Atheneu.

Dellaporta, S. L. \& Calderon-Urrea, A. (1993). Sex determination in flowering plants. Plant Cell, 5(3), 1241-1251.

Esau, K. (1980). Anatomia de plantas com sementes, São Paulo: Edgard Blucher/EDUSP.

Freeman, D. C., Harper, K. T. \& Charnov, E. L. (1980) Sex chance in plants: old and new observations and new hypotheses. Oecologia, 47(2), 222-232.

Gates, D.M. (1981). Biophysical ecology, New York: Springer-Verlag.

Gregg, K. B. (1975). The effect of light intensity on sex expression in species of Cycnoches and Catasetum (Orchidaceae). Selbyana, 1(2), 101-113.

Hoehne, F. C. (1938). As plantas ornamentais da flora brasílica. Boletim de Agricultura, 1(1), 247-273.

Joly, A. B. (1998). Botânica: introdução à taxonomia vegetal. São Paulo: Editora Nacional.

Karnovsky, M. J. (1965). A formaldehyde-glutaraldehyde fixative of high osmolality for use in electron microscopy. Journal of Cell Biology, 27(2), 137-138.

Kerbauy, G. B. (2009). Fisiologia Vegetal. Rio de Janeiro: Guanabara Koogan. 
Kurzweil, H., Weston, P. H. \& Perkins, A. J. (2005) Morphological and ontogenetic studies on the gynostemium of some Australian members of Diurideae and Cranichideae (Orchidaceae). Telopea, 11(4), 11-33

Moraes, C. P. \& Almeida, M. (2004). Influência climática sobre a plasticidade fenotípica de floral de Catasetum fimbriatum Lindley. Ciência e Agrotecnologia, 28(4), 942-948.

Mori, S. A., Silva, L. A. M., Lisboa, G. \& Coradin, L. (1989). Manual de manejo do herbário fanerogâmico. Ilhéus: Centro de Pesquisa do Cacau.

Nobel, P. S. (1991). Physicochermical and environmental plant physiology, New York: Academic Press.

O’Brien, T. P., Feder, N. \& McCully, M.E. (1964). Polychromatic staining of plant cell walls by toluidine blue O. Protoplasma, 59(1), 368-373.

Pedroso-de-Moraes, C. (2000). Cultivo de orquídeas. Araras: Biblioteca Duse Rüegger Ometto.

Pedroso-de-Moraes, C. (2004). Análise morfoanatômica do ovário de Catasetum fimbriatum Lindl. Boletim $C A O B$, 55(3), 75-80.

Pedroso-de-Moraes, C. \& Almeida, M. (2005). Estudo morfoanatômico do ginostêmio de Catasetum fimbriatum Lindley. Orquidario, 19(3-4), 84-90

Pedroso-de-Moraes, C., Moura, E. R. R., Silva, M. C. \& Abdalla, M. A. (2007). As orquídeas e o mercado. Boletim CAOB, 66/67(3), 38-42.

Perleberg, T. D., Gomes, J. C. C. \& Vargas, D. M. (2008). $\mathrm{O}$ gênero Oncidium Sw. (Orchidaceae) no sul do Rio Grande do Sul, Brasil. BioScriba, 1(2), 76-79.

Pridgeon, A. M., Cribb, P. J., Chase, M. W. \& Rasmussen, F. N. (1999). Genera Orchidacearum: General Introduction, Apostasioideae, Cypripedioideae, vol. 1. Oxford: Oxford University Press.

Pridgeon, A. M., Cribb, P. J., Chase, M. W. \& Rasmussen, F. N. (2001). Genera Orchidacearum: Orchidoideae (Part 1), vol. 2. Oxford: Oxford University Press.
Pridgeon, A. M., Cribb, P. J., Chase, M. W. \& Rasmussen, F. N. (2003). Genera Orchidacearum: Orchidoideae (Part 2), Vanilloideae, vol. 3. Oxford: Oxford University Press. Pridgeon, A. M., Cribb, P. J., Chase, M. W. \& Rasmussen, F. N. (2006). Genera Orchidacearum: Epidendroideae (Part 1), vol. 4. Oxford: Oxford University Press.

Pridgeon, A. M., Cribb, P. J., Chase, M. W. \& Rasmussen, F. N. (2009). Genera Orchidacearum: Epidendroideae (Part 2), vol. 5. Oxford: Oxford University Press.

Rasmussen, F. N. (1985). The gynostemium of Bulbophyllum ecornutum (J.J. Smith) J.J. Smith (Orchidaceae). Botanical Journal of Linnean Society, 91(3), 447-456.

Romero, G. A. (1992). Non-functional flowers in Catasetum orchids (Catasetinae, Orchidaceae). Botanical Journal of the Linnean Society, 109(2), 305-313.

Rudall, P. J. \& BATEMAN, R. M. (2002). Roles of synorganisation, zygomorphy and heterotopy in floral evolution: the gynostemium and labellum of orchids and other lilioid monocots. Biology Review, 77(2), 403-44.

Solereder, H. \& Meyer, (1930) F.J. Systematishe anatomie der monokotyledonen, v. 6. Berlin: Springer-Verlag.

Soukup, V.G. (1976). Catasetum barbatum Lindl: Male, female and hermaphroditic flowers on a Brazilian plant. American Orchid Society Bulletim, 45(7), 603-605.

Swamy, B. G. L. (1948). Vascular anatomy of orchid flowers. Botanical Museum leaflets Harvardy University, 13(2), 61-95.

Taiz, L. \& Zeiger, E. (2006). Fisiologia vegetal, São Paulo: Artmed.

Zar, J. H. (1999). Biostatistical analysis. Upper Saddle River. Prantice Hall.

Zimmerman, J. K. (1990). Role of Pseudobulbs in Growth and Flowering of Catasetum viridiflavum (Orchidaceae) American Journal of Botany, 77(4), 533-542.

Zimmerman, J, K. (1991). Ecological correlates of labile expression in the orchid Catasetum viridiflavum. Ecology, 72(2), 597-608. 